\title{
Introducing Javanese Culture Through Selected Texts in EFL Class
}

\author{
Kaukabilla Alya Parangu ${ }^{1}$ Esti Ratih ${ }^{2}$, Sevian Tri Prasetyaningrum ${ }^{3}$ \\ IAIN Ponorogo ${ }^{1}$, Sebelas Maret University ${ }^{2,3}$ \\ e-mail: ${ }^{1}$ kaukabilla@gmail.com, ${ }^{2}$ chitax.area@gmail.com, ${ }^{3}$ seviantriprasetyaningrum1@gmail.com
}

Keywords:

Culture, Selected texts, EFL

Class, Javanese culture

\begin{abstract}
A B S T R A C T
This paper presents an overview of the research on teaching Javanese culture and describes the association between Javanese culture and English language teaching (ELT) through selected texts. A decisive question occurs in terms of ELT, whether to teach culture along with English. The implementation of selected text is one of the effective ways to encourage students to be more appreciated and feel affection for their own culture. Using Javanese culture text means that the texts learned by the students are part of the Javanese original culture. This article shows the relation about the connection among literature and studies. This research also discusses a theoretical frame based on the experts' insights and opinions. To summarize, this research displays various viewpoints in relation to this topic, offers different practical studies, and reaches some valuable conclusions.
\end{abstract}

\section{INTRODUCTION}

Indonesian traditional culture, especially Javanese culture is rarely known by the several citizen mostly by the youngsters. Due to the globalization era where people can easily have access to information all over the world creates the generations that gradually do not aware to their own traditional culture and start recognizing and loving inter-cultural, unfortunately they even reckon them as their own cultures.

Learning language means learning its culture since language and culture have a tangled and inter-reliant association. Mitchell and Myles (2004) in Tran-Hoang-Tu, 2010 argue that "language and culture are not separate, but are acquired together, with each providing support for the development of the other" (p. 235).

When EFL students learn a foreign language, they inevitably receive the other culture, the language classroom must both implicitly and explicitly address the cultural elements of the targeted language. However, the language teachers should not be after 'enculturation', which according to Corbertt (2003) "the assimilation of learners into the host culture", in their classrooms while they are exposing their learners with the culture of the target language. They, conversely, should be finding ways to foster 'acculturation' which, again in Corbett's words, is "the process by which learners are encouraged to function within the new culture while maintaining their own culture. However, this paper will first critically analyze the association between Javanese culture and English language teaching (ELT) through selected texts. 


\section{METHOD}

This study explored the implementation of selected text in EFL classroom. This study is descriptive qualitative study. The selected texts in this study were taken from local culture especially Javanese culture. Javanese culture text is a text that contains value or history or belief or ways related to Javanese culture.

\section{RESULTS AND DISCUSSION}

\section{A. Teaching cultures in an EFL context}

Teaching cultures in English Foreign Language sometimes makes the students forget about their cultures. Dealing with learning foreign language, cultures have significant role both English cultures and the native culture, the searcher should increase student' motivation and engagement that can help overcome past issues of stereotyping and lack of intercultural awareness, especially their own cultures. The teacher should create a rich and meaningful environment in which students interact with authentic data and build their own understanding of a foreign culture's products, practices, and perspectives.

Professional conferences and journals focused on cultural learning "as an instructional objective equally as important as communication" (Moore, 2006, p. 4). While language teachers have acknowledged the need to integrate more cultural activities in order to encourage students' cultural and intercultural acceptance to the question lingers as to how such cultural teaching should and could most effectively take place at the classroom level.

The purpose of this article is to summarize the research related to the teaching of culture that describes effective teaching cultures and can be integrated into the second language curriculum in ways that engage learners actively in the acquisition of language and culture. This overview will attempt to advance an approach to the teaching of culture and language through the theoretical construct of the 3Ps (Products, Practices, Perspectives) (National Standards in Foreign Language Education Project, 1999), or content, combined with an inquiry teaching approach (pedagogy) utilizing digital media (instructional technology) and provide guidelines for successful classroom application. The content that is used in teaching cultures is Javanese cultures.

Through authentic, collaborative, and contextualized learning tasks that result in digital products for an audience are well documented in the research (Maor \& Roberts, 2011). When teachers integrate powerful technological tools into their instruction, students are allowed to personally interact with real data and solve open-ended problems. Integrating technology in this manner places the majority of responsibility for negotiating meaning in the hands of the learners. is learner-centered approach allows students to start with what they know and build their own understanding of culture. The integration of content, pedagogy, and instructional technology when constructing knowledge promotes a rich and engaging learning environment for foreign language learners. In addition, the authors will review the research that illustrates how teachers can utilize more traditional methods of teaching culture (e.g., folklore, fairytales, authentic pictures, art, etc.) and improve them with technology to make them more effective.

\section{B. Culture in a Foreign Language Classroom}


Research on teaching culture has shown that language and culture are closely related (e.g., Brown, 2007; Kramsch, 1998; Kuang, 2007; Savignon \& Sysoyev, 2005; Schulz, 2007; Tang, 1999) and are best acquired together (Schulz, 2007). Brown (2007) describes the interrelatedness of language and culture stating "that one cannot separate the two without losing the significance of either language oris also the acquisition of a second culture" (p. 189-190). Based on these indings, it is clear that language and culture learning are inextricably linked, but what role does culture play in language teaching and how is it being taught?

Lafayette (1988) noted that teachers spent the greatest amount of time and efort on teaching grammatical and lexical components of the language, leaving the culture as the weakest component in the curriculum.

\section{Selected Texts in EFL Class}

By using the selected texts to be used in English Foreign Language class, the language teacher should take into account needs, motivation, interests, cultural background and language level of the students. Giving the selected texts to the Moral, cultural and social values could be inculcated in language classrooms through the use of texts which is a source of qualitatively demanding authentic language with an unmistakably individual human voice behind it (that) deals with everyday life occurrences (Hall, 1999, p.11 in Yusoff, 2004). Culture is close with the students' life. In EFL class, these factors are applicable as long as the teacher scaffolds through appropriate teaching particularly when dealing with culturally unfamiliar texts (Isenberg, 1990 in Yusoff, 2004). If the text was culturally familiar, the teacher could draw on the students' cultural background as a resource. By considering the previous case, the texts for teaching should be selected with dealing culturally. If the text was students can be an approach to increasing the students in the learning process. According to Worthley, 1999 in Royani 2013, a cultural group' values and traditional lifestyle may, through child-rearing practices, influence the learning styles the individual will develop.

To make English teaching and learning meaningful, it is crucial that culture should be incorporated with the students' learning. Therefore teaching culture in EFL class can use local culture texts. Local culture texts are selected according culture where the students live. It means that the students are common with culture. The selected texts in this study were taken from local culture especially Javanese culture. Javanese culture text is a text that contains value or history or belief or ways related to Javanese culture.

\section{Implementation of Teaching Javanese Culture through Selected Texts in EFL Class}

Teaching language involved the teaching of culture as well, teaching culture through selected texts was implemented at the level of study. The teachers only needed to give the students a text that related to Javanese culture texts. the selected culture text was the topic or theme which was placed in the text. The Javanese Culture text had many things which could be used for the topic of text. 
Teaching Javanese culture through selected texts was applied in elementary school. The selected text could be used in a basic text. The example of Javanese culture text was found in the following text.

\section{Yogyakarta's Kraton}

At the center of Yogyakarta lies a city within the city: the Kraton. Built in the middle of the eighteenth century, this walled-city serves as the home of the sultans of what remains of the Mataram kingdom to this day. The palace is open to guided tours for properly dressed guests. Inside you'll find many shady courtyards connected by beautifully decorated covered walks.

The selected text above was Javanese culture text. The text had a social purpose to describe about Yogyakarta's Kraton. The students also got a culture inside. Teaching Javanese culture through selected texts was applied in Junior High School. One of the types of text is descriptive text. According to Corbett (1983) in Nasution (2011) that descriptive text is one of the expository writing. The following was the example of description text.

\section{REOG}

Reog is a traditional dance that become the main identity for Ponorogo regency.

Because of this, Ponorogo is also known as Reog city. This theatre has been known wide in Indonesian even foreign tourists. Reog National Festival is held every years along the anniversary of Ponorogo regency and Grebeg Suro celebration. Reog dance is also staged full moon nightly in paseban, Ponorogo Town Square. Reog told about the struggle for a prince who will propose to a lovely pretty princess. This dance is staged about 25 - 40 dancers and the musician. The interesting of Reog is his main leading figure named Singo Barong. The dancer of Singo Barong bear the mask about $30-40 \mathrm{~kg}$ weight and supported by the strength of their teeth. The other leading figure in Reog include Kelono Sewandono, Bujang Anom, Jatil and Warok. The visitors can enjoy this traditional dance only in Ponorogo, East Java - Indonesia. The only area that has REOG dance is Ponorogo, not in other country.

The selected text above was Javanese culture text. The text had a social purpose to describe about Reog so the students knew traditional dance from Ponorogo, East Java. The students also got a culture value.

Teaching Javanese culture through selected texts was applied in Senior High School, there were many kinds of text that were taught in Senior High Senior. One of them was narrative text, the Javanese culture text could be interpreted in the narrative text. According to Crystal (2008) in Yantu ( 2013) a narrative text is a story that is told conveyed to recipient and his 
telling requires a medium, it is converted into sign. The following was a narrative text entitled Legend of Prambanan Temple.

\section{The Legend of Prambanan Temple}

Once, there was a beautiful Javanese princess whose name was Rara Jonggrang. Rara Jonggrang whose beauty was very famous in the land was the daughter of Prabu Baka, and evil king.

One day, a handsome young man with super natural power named Bandung Bondowoso defatted and killed Prabu Baka. On seeing Princess Rara Jonggrang's beauty, Bandung Bondowoso fell in love wither and wantted to marry her.

Meanwhile, Princess Rara jonggrang felt sad due to her death father. She did not want to marry Bandung because he had killed her father. But she was also afraid of Bandung. So to refuse politely, she made a condition. "I will marry you but you have to build one thousand temples in one night as a wedding gift" requested Rara Jonggrang. Bandung Bondowoso agreed with the condition. Helped by the spirit of the demons, Bandung Bondowoso started building the temples. Approaching midnight, the work would nearly be done. Rara Jonggrang knew and thought, "What shall I do? Bandung Bondowoso is smarter than I. I would lose against Bandung."

Suddenly she got an idea. She woke up all the women in the palace and ordered them to make the noisy sounds of grinding rice so that the rooster thought at had already been dawn. Bandung Bondowoso got frustrated because he failed completing the thousandth temple.

"The Princess has deceived me!" Following his anger, he cursed Roro Jonggrang, "You have been cheated. Now, the thousandth temple is you!"

At once, the Princess turned into a statue knowing this, Bandung Bondowoso regretted and he went away into a farm land. From then people called the temple Prambanan Temple and the Princess statue Rara Jonggrang statue.

The selected text above was Javanese culture text, the students could understand the story as it was the well-known Javanese story of Roro Jonggrang, whose statue may be seen in the famous temple at Prambanan, was presented here interactively. The students also got a culture value from comprehending the text, not to mention, they also knew a culture that this legend was part of the mystique surrounding Candi Prambanan and invoked historical impressions of the ancient kingdoms of Java.

\section{CONCLUSION}

Teaching culture is crucial to be conducted since most of the youngsters have no awareness to their own cultures, especially in Javanese. Learning a foreign language will inevitably involve the other culture, since language and culture can't be separated. The language 
classroom itself must both implicitly and explicitly address the cultural elements of the targeted language In order keep the local culture when learning English, the teacher needs to insert some Javanese cultural values in this subject. One of the ways is selecting an appropriate text when teaching EFL, selected text is chosen because the teachers are the people who know best their students' need. Therefore, the use of local is very useful.

\section{REFERENCES}

Nasution, Amir H. (2011). The Teachers' Strategies in Overcoming the Students' Difficulties in Writing Descriptive Text. Cirebon: IAIN Syekh Nurjati

Royani, Miftah. (2013). The Use of Local Culture Texts for Enthuasiastic English Reading, Vol.7 No. 1

Tu, Tran Hoang. (2010). Teaching Culture in the ESL/EFL Classroom. California:

Yantu, Yuni F.S. (2013). Developing Students' Ability in Writing Narrative Text by Using Story Map Technique. Gorontalo: Gorontalo State University

Yusoff, Zailin S. (2004). Cultural Familiarity in Literary Texts: Consideration for TextSelection. U-TEC.

J. Corbett. An Intercultural approach to English language teaching. Clevedon: Multilingual Matters Ltd., 2003. 